\begin{tabular}{l|l} 
Jurnal Eksplorasi Akuntansi & $\begin{array}{l}\text { e-ISSN : 2656-3649 (Online) } \\
\text { Vol. 3, No 3, Agustus 2021, Hal 653-671 }\end{array}$
\end{tabular}

\title{
Pengaruh Faktor Keuangan dan Karakteristik Pemerintah Daerah Terhadap Financial Distress \\ (Studi Empiris Kabupaten/Kota di Provinsi Aceh Tahun 2015-2019)
}

\author{
Rahima Zakia ${ }^{1 *}$, Mia Angelina Setiawan ${ }^{2}$ \\ ${ }^{1,2}$ Fakultas Ekonomi, Universitas Negeri Padang \\ *Korespondensi: rahimazakia9@gmail.com
}

\begin{abstract}
This study is a quantitative research that aims to obtain empirical evidence about the influence of financial factors (effectiveness ratio, efficiency ratio, solvency ratio and growth ratio) and characteristics of local government (decentralization degree, complexity of local government, area size and audit opinion) on local government financial distress in districts and cities in Aceh Province for the period 2015-2019 for 5 years. The data was obtained from the BPK and BPS. This research used a total sampling method with total sample of 23 districts / cities and used binary logistic regression analysis for analysis of the data. The value of desentralization degree and complexity of local government has a negative and significant effect on financial distress and the value of growth ratio has a positive and significant effect on financial distress. While the value of solvency ratio and area size has no significant effect and positive on financial distress and the value of effectiveness ratio, efficiency ratio and audit opinion has no significant effect and negative on financial distress.
\end{abstract}

Keywords : financial factors; characteristics of local government; financial distress.

How to cite (APA $6^{\text {th }}$ style)

Zakia, Rahima \& Setiawan, MA. (2021). Pengaruh Faktor Keuangan dan Karakteristik Pemerintah Daerah Terhadap Financial Distress (Studi Empiris Pada Kabupaten/Kota di Provinsi Aceh Tahun 2015-2019). Jurnal Eksplorasi Akuntansi. 3(3). 653-671.

\section{PENDAHULUAN}

Berdasarkan hasil risest Ombudsman akhir tahun 2017 menunjukkan fakta bahwa sebagian besar pelayanan publik di Indonesia masih memiliki rapor merah. Pada diskusi pertengahan 2019 pun disampaikan bahwa tingkat pelayanan publik Indonesia semakin rendah. Ketika pelayanan publik masih buruk maka menunjukkan ketidakmampuan pemerintah dalam memberikan pelayanan yang baik kepada masyarakat. Ketidakmampuan pemerintah dalam memenuhi pelayanan yang sesuai standar kepada masyarakat yang diakibatkan oleh ketidakcukupan dana pemerintah daerah dalam menyediakan infrastruktur publik karena kurangnya alokasi belanja modal merupakan kondisi financial distress (Jones dan Walker, 2007).

Dalam pelayanan publik pemerintah untuk masyarakat, belanja modal memiliki peranan penting karena jumlah persentase dana yang dialokasikan untuk belanja modal akan memberikan dampak pada pembangunan untuk memberikan pelayanan yang memadai bagi masyarakat. Porsi minimal belanja modal terhadap belanja daerah adalah $30 \%$ yang tertuang 
pada Peraturan Presiden Republik Indonesia nomor 2 tahun 2015 tentang Rencana Pembangunan Jangka Menengah Nasional (RPJMN). Berdasarkan informasi yang dipublikasikan oleh Kementerian Keuangan Republik Indonesia disebutkan bahwa belanja modal yang digunakan untuk pembangunan infrastruktur persentasenya masih terbilang kecil dibanding dengan belanja pegawai dan belanja barang jasa. Provinsi di Indonesia yang telah memenuhi belanja modalnya sesuai data APBD 2019 adalah 29 Provinsi, sedangkan provinsi yang belum mampu memenuhi kewajiban belanja modalnya terdapat 5 provinsi yaitu provinsi Papua, provinsi Aceh, provinsi Jawa Timur, provinsi Papua Barat dan provinsi Sulawesi Barat. Provinsi dengan persentase terendah yaitu provinsi Papua yang persentasenya 3,56\%.

Istilah financial distress pertama kali dikenal di sektor swasta dan diartikan sebagai suatu kondisi dimana perusahaan mengalami kegagalan dalam memenuhi kewajiban keuangannya. Namun tidak menutup kemungkinan kondisi ini terjadi pada sektor publik seperti pemerintahan, yang dibuktikan oleh penelitian Jones dan Walker (2007) yang meneliti tentang financial distress di New South Wales Negara Bagian Australia. Penelitian tersebut mengidentifkasi faktor-faktor yang mempengaruhi financial distress di pemerintah daerah sebagai ketidakmampuan pemerintah daerah dalam mempertahankan pelayanan yang sesuai standar akibat kurangnya porsi belanja modal yang ditujukan untuk investasi pada pemerintahan. Di Indonesia kondisi financial distress terbukti dalam laporan evaluasi belanja modal yang diterbitkan oleh Direktorat Jenderal Perimbangan Keuangan tahun 2013 yang menyatakan penyerapan belanja modal di pemerintah daerah masih rendah. Hal ini menunjukkan bahwa kinerja pemerintah daerah masih belum efektif dan efisien dalam mengoptimalkan belanja modal yang berguna dalam peningkatan pelayanan publik.

Laporan keuangan merupakan salah satu tolak ukur dalam menilai kinerja pemerintah daerah, karena laporan keuangan adalah bentuk pertanggungjawaban pemerintah daerah atas kinerjanya dalam mengelola keuangan daerah dalam periode tertentu. Cara yang dapat dilakukan dalam menganalisis laporan keuangan pemerintah daerah yaitu melakukan pengukuran dengan rasio keuangan. Sutaryo, et al (2012) membuktikan bahwa laporan keuangan pemerintah daerah dapat memprediksi status financial distress pemerintah daerah. Sehingga informasi dalam laporan keuangan dianggap relevan untuk pengambilan keputusan. Tidak hanya itu, rasio keuangan juga dapat memengaruhi financial distress suatu daerah karena dengan diperolehnya hasil persentase rasio keuangan ini, pemerintah daerah dapat melakukan evaluasi pada kinerjanya yang tercermin dalam rasio keuangan.

Kinerja pemerintah daerah juga dapat dinilai dengan karakteristik pemerintah daerah. Sutaryo (2012) menyebutkan bahwa perusahaan memiliki karakteristik yang dapat menilai kinerja perusahaan. Begitupun halnya dengan pemerintah daerah yang juga memiliki kekhasan masing-masing daerah yang membedakan suatu daerah dengan daerah lainnya. Ciri khas tersebut akan berdampak pada kinerja pemerintah daerah sehingga menentukan pelayanan publik yang diberikan pemerintah daerah kepada masyarakat.

Penelitian ini mengacu pada penelitian Syurmita (2014) yang menunjukkan bahwa derajat desentralisasi dan jumlah penduduk berpengaruh signifikan terhadap kondisi financial distress. Penelitian Indriaty (2016) menunjukkan rasio hutang dan opini audit berpengaruh terhadap financial distress. Husniati (2016) yang menunjukkan kemandirian keuangan, rasio solvabilitas, rasio efisiensi dan kompleksitas pemerintah daerah terhadap financial distress sedangkan derajat desentralisasi berpengaruh terhadap financial distress. Windiyanti dan Isfaatun (2017) menunjukkan bahwa rasio solvabilitas dan kompleksitas tidak berpengaruh terhadap financial distress. Penelitian Sari dan Arza (2019) membuktikan bahwa derajat desentralisasi, kompleksitas pemerintah daerah dan luas wilayah berpengaruh terhadap kondisi financial distress. Wulandari dan Arza (2020) menunjukkan bahwa opini audit tidak berpengaruh terhadap financial distress. Cheisviyanny et.al (2020) menunjukkan bahwa 
derajat desentralisasi, jumlah penduduk, usia pemerintahan dan luas wilayah berpengaruh terhadap kondisi financial distress di Indonesia.

Terdapat perbedaan hasil penelitian pada penelitian sebelumnya. Sehingga penulis meneliti kembali mengenali kondisi financial distress dengan beberapa perbedaan dengan penelitian sebelumnya, yakni pada penelitian Syurmita (2014) dan Husniati (2016) rasio-rasio digunakan sebagai variabel independen yang memengaruhi prediksi financial distress di pemerintah daerah Indonesia sedangkan pada penelitian Wulandari dan Arza (2020) menggunakan rasio-rasio sebagai variabel independen yang memengaruhi financial distress di pemerintah daerah Sumatera Barat. Maka dari itu variabel independen yang digunakan pada penelitian ini adalah variabel faktor keuangan yang terdiri dari rasio efektivitas yang menggambarkan kemampuan pemerintah daerah dalam merealisasikan pendapatan daerah yang telah direncanakan dibandingkan dengan target yang telah ditetapkan. Rasio efisiensi menggambarkan bagaimana pemerintah daerah dapat menekan belanja langsung untuk kegiatan operasionalnya sehingga dapat dialihkan ke belanja modal untuk infrastruktur dan pelayanan masyarakat. Rasio solvabilitas yang menggambarkan kemampuan pemerintah dalam melunasi kewajibannya. Rasio pertumbuhan dapat mengevaluasi potensi masingmasing daerah yang memerlukan perhatian dari pemerintah daerah.

Variabel karakteristik pemerintah daerah yang terdiri dari derajat desentralisasi yang menggambarkan kontribusi pendapatan asli daerah dalam penyelenggaraan desentralisasi, Pendapatan Asli Daerah (PAD) merupakan tingkat kekuatan pemerintah dalam mengatur dan mengurus daerahnya. Kompleksitas pemerintah daerah yang dapat menentukan pelayanan oleh pemerintah daerah. Luas wilayah yang menggambarkan cakupan besarnya pelayanan pada suatu daerah. Opini audit yang merupakan pernyataan profesional tentang kewajaran laporan keuangan pemerintah daerah, opini audit melibatkan kinerja pemerintah daerah sehingga dapat menentukan kondisi financial distress suatu daerah.

Studi empiris atau objek penelitian yang digunakan pada penelitian ini adalah Kabupaten/Kota di Provinsi Aceh. Provinsi Aceh tercatat sebagai provinsi yang belum mampu memenuhi belanja modalnya. Padahal Provinsi Aceh merupakan provinsi yang diberi kewenangan otonomi khusus yang artinya mendapat bantuan dana khusus dari pemerintah pusat. Dana pembangunan di Aceh yang terbesar berasal dari dana otonomi khusus dan penerimaan daerahnya pun $50 \%$ berasal dari dana otonomi khusus. Namun dana otonomi khusus di Aceh yang diketahui meningkat sejak tahun 2008 tidak digunakan secara merata untuk pembangunan infrasruktur, pendidikan dan kesehatan (CNBC Indonesia, 2020). Kabupaten di Provinsi Aceh yang terdiri dari 18 Kabupaten, rata-rata realisasi belanja modalnya dari rentang tahun 2015-2019 adalah 26,44\%. Kabupaten yang mampu memenuhi kewajiban modalnya melebihi 30\% adalah 4 kabupaten, yakni Kabupaten Pidie Jaya, Nagan Raya, Aceh Barat Daya dan Gayo Lues. Sedangkan 5 kota di Provinsi Aceh memiliki rata-rata realisasi belanja modal $25,36 \%$, hanya 1 kota yang mampu memenuhi kewajiban belanja modalnya yaitu Kota Subussalam. Artinya dalam rentang waktu tahun 2015 sampai dengan tahun 2019 rata-rata realisasi belanja modal kabupaten/kota di Provinsi Aceh masih rendah dan menandakan bahwa persentase yang disebutkan diatas masih jauh dari porsi minimal dari alokasi belanja modal. Kondisi ini menggambarkan adanya resiko financial distress pada kabupaten/kota di Provinsi Aceh. Penelitian ini bertujuan untuk memperoleh bukti empiris mengenai kondisi financial distress pada kabupaten/kota di Provinsi Aceh dan faktor-faktor yang mempengaruhinya.

\section{REVIU LITERATUR DAN HIPOTESIS}

\section{Teori Keagenan}

Teori ini dikembangkan oleh Jensen and Meckling (1976) yang menunjukkan bahwa teori keagenan adalah hubungan kontrak antara prinsipal dan agen, namun hubungan ini tidak 
selamanya lancar dan kerap terjadi konflik kepentingan diantara keduanya. Hubungan keagenan yang terjadi pada sektor publik adalah hubungan keagenan antara pemerintah dan legislatif yang terlihat dalam penyusunan anggaran eksekutif cenderung akan mengusulkan anggaran belanja yang lebih besar dari yang fakta yang terjadi saat ini (asas maksimal) sedangkan pada anggaran pendapatan eksekutif cenderung mengusulkan yang lebih rendah (asas minimal) agar ketika realisasi dilaksanakan targat tersebut lebih mudah dicapai.

Dalam menjalankan tugas dan fungsinya, eksekutif cenderung memilih posisi yang aman dan nyaman, namun tidak mementingkan publik. Legislatif sebagai prinsipal dalam penganggaran seharusnya membela kepentingan masyarakat yang diwakilinya dengan mengakomodasi kebutuhan publik dalam anggaran. Namun karena perilaku opportunistik legislatif, legislatif cenderung mengusulkan anggaran yang meningkatkan penghasilannya sehingga dapat memenuhi self interestnya dalam jangka pendek (Garamfalvi, 1997 dalam Halim dan Abdullah, 2012).

\section{Teori Ketergantungan Sumber Daya}

Teori ini tercipta karena eksploitasi yang dilakukan oleh negara maju terhadap negara miskin sehingga terciptanya ketergantungan teknologi dan sumber daya dari negara miskin kepada negara maju. Teori ini menggambarkan konsep kekuasaan pada suatu organisasi. Organisasi yang memiliki kekuasaan akan berhubungan dengan lingkungan sekitar terkait tugas dan wewenangnya (Paul, 2016). Organisasi beroperasi dalam sistem terbuka untuk bertahan hidup sehingga menciptakan ketergantungan terhadap organisasi lain untuk memperoleh sumber daya, dalam mempertahankan dan memperoleh sumber daya, organisasi meningkatkan ketergantungan organisasi lain kepadanya (Balcilar, 2017). Pandangan teori ini pada sektor publik adalah ketergantungan pemerintah daerah kepada pemerintah pusat dalam mengatur dan mengelola pemerintahannya sendiri, jika dana yang dibutuhkan tidak memadai maka pemerintah daerah akan bergantung pada dana pemerintah pusat.

\section{Financial Distress}

Financial distress merupakan istilah yang biasa digunakan pada perusahaan ketika terjadinya kesulitan keuangan. Kesulitan keuangan pada perusahaan ini umumnya ditandai dengan ketidakmampuan perusahaan dalam membayar kewajibannya, kegagalan perusahaan dalam membayar dividen, kekurangan modal kerja dan ketidakcukupan dana untuk membayar sejumlah biaya perusahaan. Apabila kondisi kesulitan keuangan ini tidak segera ditindaklanjuti, maka kondisi tersebut akan semakin parah hingga berujung kebangkrutan (Andre dan Taqwa, 2014). Pada organisasi sektor publik, financial distress didefinisikan sebagai ketidakmampuan pemerintah daerah dalam memberikan pelayanan yang sesuai standar kepada masyarakat. Hal ini disebabkan oleh kurangnya kemampuan manajerial dalam mengalokasikan belanja modal sehingga pemerintah daerah tidak maksimal dalam berinvestasi pada infrastruktur publik dan pembangunan yang berguna untuk mensejahterakan dan memberi pelayanan yang sesuai standar mutu kepada masyarakat (Jones dan Walker, 2007).

\section{Faktor Keuangan}

Rasio keuangan dapat didefinisikan sebagai pengungkapan perbandingan antara satu pos dengan pos lainnya dalam laporan keuangan. Rasio keuangan berguna bagi analis internal untuk membantu manajemen dalam mengevaluasi hasil-hasil operasi entitas, memperbaiki kesalahan-kesalahan dan menghindari keadaan yang dapat menyebabkan kesulitan keuangan. Kondisi keuangan pemerintah daerah dapat dinilai melalui analisis rasio keuangan yang terdapat dalam informasi laporan keuangan meskipun berbeda dengan yang dengan sektor swasta. 
Penyusunan laporan keuangan pemerintah merupakan wujud dari transparansi dan akuntabilitas pengelolaan keuangan daerah (Atmaja, 2012). Analisis rasio keuangan yang dilakukan dapat dilakukan sebagai standar evaluasi kinerja pemerintah daerah sehingga rasio keuangan (rasio efektivitas, rasio efisiensi, rasio solvabilitas dan rasio pertumbuhan) dapat memengaruhi financial distress pada pemerintah kabupaten/kota di Provinsi Aceh.

\section{Karakteristik Pemerintah Daerah}

Menurut KBBI, karakteristik merupakan ciri-ciri khusus, mempunyai sifat khas. Karakteristik pemerintah daerah dapat diartikan sebagai ciri-ciri khusus suatu daerah sehingga hal tersebut menjadi kekhasan suatu daerah yang membedakannya dengan daerah lain. Karakteristik daerah dapat digambarkan dan diukur melalui hal-hal yang menjadi indentitas daerah tersebut. Karakteristik pemerintah daerah yang digunakan pada penelitian ini adalah derajat desentralisasi, kompleksitas keuangan pemerintah daerah, luas wilayah dan opini audit. Masing-masing variabel tersebut dapat mempengaruhi financial distress pada kabupaten/kota di provinsi Aceh.

\section{Hubungan Rasio Efektivitas Terhadap Financial Distress}

Rasio efektivitas dapat menggambarkan kinerja keuangan pemerintah daerah. Rasio efektifitas yang tinggi memberi gambaran kinerja pemerintah daerah yang baik dan menandakan kemampuan daerah merealisasikan pendapatan daerahnya sesuai dengan target yang telah ditetapkan (Lazyra, 2016). Teori ketergantungan menyebutkan bahwa pemerintah daerah yang tidak memiliki ketergantungan kepada pemerintah pusat akan mampu mengatur dan mengelola keuangan daerahnya sendiri. Sehingga hal tersebut dapat meminimalisir terjadinya financial distress pada suatu daerah. Apabila rasio efektifitas tinggi maka indikasi pemerintah daerah mengalami financial distress akan rendah, sebaliknya rasio efektifitas rendah maka indikasi pemerintah daerah mengalami financial distress akan tinggi. Penelitian yang dilakukan oleh Ardhini (2011) dan Fitri, dkk (2013) menunjukkan bahwa rasio efektivitas berpengaruh positif terhadap Financial Distress sedangkan penelitian Wulandari dan Arza (2020) menunjukkan bahwa rasio efektivitas berpengaruh negatif dan tidak signifikan terhadap financial distress.

H1: Rasio efektifitas berpengaruh negatif terhadap financial distress.

\section{Hubungan Rasio Efisiensi Terhadap Financial Distress}

Rasio efisiensi menggambarkan kemampuan pemerintah daerah dalam melaksanakan kegiatan operasional namun dengan dana yang serendah-rendahnya. Pemerintah daerah dapat dikatakan efisien apabila kegiatan operasional yang dilaksanakan mencapai target dengan dana yang seminimal mungkin (Lazyra, 2016). Semakin kecil rasio efisiensi maka kinerja pemerintah daerah akan semakin bagus dan indikasi pemerintah daerah mengalami financial distress juga rendah. Rasio efisiensi yang kecil menandakan pemerintah daerah mampu menekan biaya operasionalnya dibandingkan dengan realisasi pendapatan daerahnya sehingga dana tersebut dapat dialihkan ke belanja modal pemerintah daerah dalam memberikan pelayanan kepada pembangunan dan infrastruktur untuk masyarakat. Penelitian Ardhini (2011), Wulandari dan Arza (2020) menunjukkan bahwa rasio efisiensi berpengaruh positif dan tidak signifikan terhadap Financial Distress. Sedangkan penelitian Fitri dkk (2013) berpengaruh negatif dan tidak signifikan terhadap Financial Distress.

H2: Rasio efisiensi berpengaruh positif terhadap financial distress.

\section{Hubungan Rasio Solvabilitas Terhadap Financial Distress}

Rasio solvabilitas menggambarkan kemampuan pemerintah daerah dalam melunasi kewajibannya dengan sumber daya yang ada dan pendapatan daerahnya. Ketersediaan sumber 
daya untuk melunasi hutang merupakan sinyal kemampuan organisasi dalam memenuhi komitmen keuangan (Syurmita, 2014). Semakin banyak aset yang dibiayai oleh hutang maka akan semakin besar kesulitan keuangan daerah karena pemerintah daerah memiliki kewajiban yang besar untuk membayar hutang. Sehingga rasio solvabilitas yang tinggi menandakan pemerintah daerah tidak mampu dalam mengalokasikan belanja modalnya (Waninda dan Arza, 2019). Penelitian Syurmita (2014), Atmaja (2012) dan Indriaty (2016) menunjukkan bahwa rasio solvabilitas berpengaruh terhadap financial distress sedangkan pada penelitian Pratiwi (2014) dan Husniati (2016) menunjukkan bahwa rasio solvabilitas berpengaruh tidak signifikan terhadap financial distress.

H3: Rasio solvabilitas berpengaruh positif terhadap financial distress.

\section{Hubungan Rasio Pertumbuhan Terhadap Financial Distress}

Rasio pertumbuhan menggambarkan keberhasilan pemerintah daerah dalam mempertahankan dan meningkatkan kinerja yang telah dicapainya dari satu periode ke periode berikutnya. Rasio ini berguna untuk menilai kemampuan pemerintah daerah dalam mengelola pendapatan keuangan daerah dan untuk mengevaluasi potensi-potensi keuangan daerah yang perlu mendapat perhatian. Rasio pertumbuhan yang positif menunjukkan bahwa pemerintah daerah yang mampu mengalokasikan belanja modalnya dengan baik dan melebihi standar yang telah ditetapkan dan menandakan pemerintah daerah mampu berinvestasi dengan baik yang artinya pemerintah daerah tidak mengalami financial distress (Wulandari dan Arza, 2020).

H4: Rasio pertumbuhan berpengaruh negatif terhadap financial distress.

\section{Hubungan Derajat Desentralisasi Terhadap Financial Distress}

Derajat desentralisasi menggambarkan kontribusi pendapatan asli daerah dalam penyelenggaraan desentralisasi. Syurmita (2014) pada penelitiannya menyebutkan bahwa pemerintah daerah yang memiliki ketergantungan terhadap dana pusat kemungkinan besar mengalami financial distress. Oleh sebab itu, semakin tinggi derajat desentralisasi pemerintah daerah, semakin kecil kemungkinan pemerintah daerah mengalami financial distress. Teori ketergantungan sumber daya menjelaskan bahwa organisasi adalah konsekuensi dari kemampuan mereka mempengaruhi, sehingga organisasi yang hidupnya tergantung pada subsidi pemerintah biasanya akan cenderung lebih taat pada aturan pemerintah pusat, namun pemerintah daerah yang tidak terlalu bergantung terhadap subsidi pemerintah pusat akan mampu mengelola pemerintahannya sendiri dengan baik. Pemerintah Kabupaten/Kota yang memiliki Pendapatan Asli Daerah (PAD) rendah akan bergantung pada transfer dana pemerintah pusat/provinsi, agar dapat mendanai program-programnya. Sedangkan Kabupaten/Kota yang memiliki Pendapatan Asli Daerah (PAD) tinggi dapat menyelenggarakan desentralisasi dengan mengandalkan pendapatan asli daerah lebih banyak, disamping dana transfer (perimbangan) (Sari dan Arza, 2019).

H5: Derajat desentralisasi berpengaruh negatif terhadap financial distress.

\section{Hubungan Kompleksitas Pemerintah Daerah Terhadap Financial Distress}

Kompleksitas pemerintah daerah pada penelitian ini diproksikan dengan jumlah penduduk yang menetap ataupun berdomisili pada suatu daerah. Penduduk memiliki kewajiban untuk mematuhi aturan pada daerah tempatnya berdomisili dan memiliki hak untuk memperoleh pelayanan publik yang diharapkan untuk mendapatkan kesejahteraan. Semakin besar jumlah penduduk akan semakin besar tingkat pelayanan publik yang harus diberikan dan akan banyak tuntutan hak kepada pemerintah daerah (Syurmita, 2014).

H6: Jumlah penduduk berpengaruh positif terhadap financial distress. 


\section{Hubungan Luas Wilayah Terhadap Financial Distress}

Daerah yang memiliki luas wilayah yang besar akan membutuhkan sarana dan prasarananya semakin banyak, luas wilayah dapat menggambarkan tindakan pemerintah daerah dalam memberikan pelayanan publik kepada masing-masing daerah. Pemerintah daerah yang wilayah lebih luas, probabilitasnya mengalami financial distress akan lebih besar (Sari dan Arza, 2019).

H7: Luas wilayah berpengaruh positif terhadap financial distress.

\section{Hubungan Opini Audit Terhadap Financial Distress}

Opini audit merupakan pernyataan profesional yang diberikan oleh auditor BPK atas kewajaran informasi laporan keuangan. Opini audit dapat meningkatkan kepercayaan stakeholder atau pemangku kepentingan terhadap pelaporan keuangan yang telah disajikan oleh pemerintah daerah dan menjadi tolak ukur menilai akuntabilitas serta memengaruhi kepercayaan publik kepada pemerintah (Indriaty, 2016). Semakin wajar opini audit, semakin kecil probabilitas pemerintah daerah mengalami financial distress.

H8: Opini audit berpengaruh negatif terhadap financial distress.

\section{METODE PENELITIAN}

\section{Jenis Penelitian}

Penelitian ini termasuk ke dalam jenis penelitian kausal yang menganalisis pengaruh variabel independen terhadap variabel dependen (Sekaran, 2017 ; 112). Metode yang digunakan untuk menganalisis pengaruh tersebut adalah metode kuantitatif. Metode ini dilakukan dengan mengumpulkan data melalui instrumen penelitian kemudian melakukan analisis data menggunakan alat statistik untuk menguji hipotesis yang telah ditetapkan.

\section{Populasi dan Sampel}

Populasi pada penelitian ini adalah kabupaten/kota di Provinsi Aceh. Teknik yang digunakan dalam pengambilan sampel adalah total sampling yang menjadikan seluruh total populasi sebagai sampel dalam penelitian yang berjumlah 23 kabupaten dan kota.

\section{Jenis dan Sumber Data}

Jenis data yang digunakan pada penelitian ini adalah data sekunder. Penelitian ini menggunakan data dari 23 kabupaten/kota di Provinsi Aceh dalam rentang waktu 2015-2019. Data tersebut bersumber dari laporan keuangan yang diperoleh dari Badan Pemeriksa Keuangan RI Perwakilan Aceh dan data yang diperoleh dari Badan Pusat Statistik Perwakilan Aceh dari tahun 2015-2019.

\section{Variabel Penelitian dan Pengukuran Variabel Dependen (Y)}

Variabel terikat pada penelitian ini adalah financial distress. Financial distress ini merupakan ketidakmampuan pemerintah dalam berbagai kegiatannya untuk memberikan pelayanan yang sesuai standar kepada masyarakat. Hal ini disebabkan oleh kekurangan dana sehingga kurangnya alokasi belanja modal untuk investasi pada infrastruktur publik (Syurmita, 2014).

$$
\text { Financial distress }=\frac{\text { Belanja Modal }}{\text { Total Belanja }}
$$




\section{Variabel Independen}

\section{Rasio Efektifitas}

Rasio efektifitas menggambarkan kemampuan pemerintah daerah dalam merealisasikan pendapatan yang telah ditargetkan dalam anggaran pendapatan dan belanja daerah.

$$
\text { Rasio Efektivitas }=\quad \frac{\text { Realisasi Pendapatan }}{\text { Anggaran Pendapatan }} \times 100 \%
$$

\section{Rasio Efisiensi}

Rasio efisiensi menggambarkan efisiensi biaya yang dikeluarkan pemerintah untuk memperoleh pendapatan dengan realisasi pendapatan yang diterima.

$$
\text { Rasio Efisiensi }=\quad \frac{\text { Realisasi Belanja Daerah }}{\text { Realisasi Pendapatan Daerah }} \times 100 \%
$$

\section{Rasio Solvabilitas}

Rasio solvabilitas menggambarkan kemampuan pemerintah daerah dalam melunasi hutangnya dengan ketersediaan sumber daya yang dimiliki.

$$
\text { Rasio Solvabilitas }=\frac{\text { Total Utang }}{\text { Total Aset }}
$$

\section{Rasio Pertumbuhan}

Rasio pertumbuhan berguna untuk melihat kemampuan pemerintah daerah atas pengelolaan pendapatan keuangan daerah di periode sebelumnya.

$$
\text { Rasio Pertumbuhan }=\frac{\text { PAD tahun } t-P A D \text { tahun } t-1}{\text { PAD tahun } t-1}
$$

5. Derajat Desentralisasi

Derajat desentralisasi menggambarkan kontribusi pendapatan asli daerah dalam penyelenggaraan desentralisasi.

$$
\text { Derajat Desentralisasi }=\frac{\text { Pendapatan Asli Daerah }}{\text { Total Pendapatan }}
$$

6. Kompleksitas Pemerintah Daerah

Penduduk merupakan sejumlah orang yang menetap pada suatu wilayah yang memiliki kewajiban untuk mematuhi aturan pada daerah tersebut dan memiliki hak untuk memperoleh pelayanan publik yang diharapkan untuk mendapatkan kesejahteraan.

$$
\text { Size }=\text { Ln Jumlah Penduduk }
$$

\section{Luas Wilayah}

Luas wilayah suatu daerah menggambarkan cakupan besarnya pelayanan yang akan diberikan oleh pemerintah daerah.

$$
\text { Luas Wilayah }=\text { Ln Luas Wilayah }
$$

\section{Opini Audit}

Opini audit merupakan pernyataan profesional yang diberikan oleh auditor BPK atas kewajaran informasi laporan keuangan yang dapat meningkatkan kepercayaan stakeholder 
atau pemangku kepentingan terhadap pelaporan keuangan yang telah disajikan oleh pemerintah daerah dan menjadi tolak ukur menilai akuntabilitas serta memengaruhi kepercayaan publik kepada pemerintah. Pengukuran opini audit dapat digunakan dengan variabel dummy, dimana $1=$ Opini Wajar Tanpa Pengecualian dan $0=$ Opini Wajar Dengan Pengecualian.

\section{Teknik Analisis Data}

Analisis data yang digunakan pada penelitian ini adalah analisis regresi linear berganda. Analisis ini digunakan untuk menguji pengaruh dua variabel independen atau lebih terhadap variabel dependen.

\section{HASIL DAN PEMBAHASAN}

\section{Gambaran Umum Objek Penelitian}

Pada penelitian ini objek penelitian yang digunakan adalah pemerintah kabupaten/Kota di provinsi Aceh yang terdiri dari 18 kabupaten dan 5 kota. Seluruh pemerintah kabupaten/kota di provinsi Aceh sekaligus dijadikan sebagai sampel, karena penelitian ini menggunakan teknik sampel total sampling dalam pengambilan sampelnya. Penelitian ini menjelaskan bagaimana kondisi pemerintah daerah kabupaten/kota di provinsi Aceh dalam memberikan pelayanan publik kepada masyarakat serta kemampuan dana keuangan pemerintah daerah dalam memenuhi kebutuhan publik yang dilihat dari belanja modal pemerintah daerah tersebut dari tahun 2015 sampai dengan tahun 2019.

Tabel 1

\begin{tabular}{lrrrrr}
\hline \multicolumn{7}{c}{ Descriptive Statistics } \\
\hline & N & Minimum & Maximum & Mean & Std. Deviation \\
Rasio Efektivitas (X1) & 115 & 76,98 & 118,30 & 96,5143 & 4,37868 \\
Rasio Efisiensi (X2) & 115 & 56,30 & 126,12 & 85,7528 & 10,20603 \\
Rasio Solvabilitas (X3) & 115 &, 00 & 16,83 & 1,9322 & 2,21255 \\
Rasio Pertumbuhan (X4) & 115 & $-28,01$ & 65,20 & 11,5237 & 18,26557 \\
Derajat Desentralisasi & 115 & 3,58 & 23,20 & 9,4354 & 3,72781 \\
(X5) & & & & & \\
Kompleksitas Pemda (X6) & 115 & 10,41 & 13,34 & 12,1237 &, 66676 \\
Luas Wilayah (X7) & 115 & 4,10 & 8,75 & 7,3909 & 1,21860 \\
Opini Audit (X8) & 115 & 0 & 1 &, 96 &, 205 \\
Financial Distress (Y) & 115 & 9,63 & 46,50 & 26,2010 & 7,07855 \\
Valid N (listwise) & 115 & & & & \\
\hline
\end{tabular}

\section{Pembahasan}

Mengacu pada hasil analisis data yang telah dilakukan maka dapat diketahui nilai Adjusted $R$ Square dari penelitian ini adalah 0,357 atau sama dengan 35,7\%. Maksud dari angka tersebut adalah variable-variabel independen yang terdapat pada penelitian ini secara keseluruhan berpengaruh terhadap variabel dependen financial distress sebesar 35,7\%. Sedangkan $64,3 \%$ sisanya dipengaruhi oleh variabel lain yang tidak diteliti.

\section{Pengaruh Rasio Efektifitas Terhadap Financial Distress}

Hasil pengujian hipotesis pertama memiliki nilai signifikansi 0,104 dan koefisien sebesar -0,241. Nilai signifikansi dari rasio efektivitas besar dari 0,05 sehingga mengambarkan bahwa rasio efektivitas berpengaruh tidak signifikan terhadap financial distress dan nilai koefisien dari rasio efektivitas yang negatif - 0,241 menunjukkan arah dari rasio efektivitas sesuai dengan arah hipotesis maka hipotesis pertama (H1) diterima. Hasil penelitian pada tabel diatas menunjukkan bahwa secara simultan rasio efektivitas berpengaruh 
negatif terhadap financial distress akan tetapi secara parsial rasio efektivitas berpengaruh negatif dan tidak signifikan terhadap financial distress.

Nilai rasio efektivitas dapat menggambarkan tingkat kemampuan kinerja pemerintah daerah dalam merealisasikan pendapatan daerahnya sesuai dengan anggaran yang telah ditetapkan namun rasio efektivitas belum tentu mampu mengukur kinerja pemerintah daerah dalam mengalokasikan belanja modal yang akan menandakan keadaan pelayanan publik pada pemerintah daerah kabupaten/kota di provinsi Aceh dari tahun 2015 sampai dengan tahun 2019. Hasil penelitian ini tidak sejalan dengan penelitian Lazyra (2016) dan Gorina, et al (2017) yang menyatakan bahwa rasio efektivitas berpengaruh signifikan terhadap financial distress serta tidak sejalan dengan teori ketergantungan sumber daya yang menyatakan bahwa rasio efektivitas dapat menunjukkan kemampuan daerah dalam mengelola anggaran pendapatan dan belanja daerahnya sendiri tanpa bantuan dari pemerintah pusat sehingga dapat memberikan pelayanan publik yang sesuai standar kepada masyarakat.

\section{Pengaruh Rasio Efisiensi Terhadap Financial Distress}

Hasil pengujian hipotesis kedua memiliki nilai signifikansi 0,770 dan koefisien sebesar -0,017. Nilai signifikansi dari rasio efisiensi besar dari 0,05 sehingga menggambarkan bahwa rasio efisiensi berpengaruh tidak signifikan terhadap financial distress. Nilai koefisiennya adalah sebesar negatif 0,017 hal ini berarti hipotesis kedua (H2) ditolak karena penelitian ini tidak dapat membuktikan bahwa rasio efisiensi berpengaruh positif dan signifikan terhadap financial distress. Hasil penelitian secara parsial adalah rasio efisiensi berpengaruh negatif dan tidak signifikan terhadap financial distress. Rasio efisiensi yang memiliki arah positif menggambarkan bahwa semakin tinggi rasio efisiensi maka dapat menunjukkan kinerja pemerintah daerah yang kurang bagus karena tidak efisien dalam mengalokasikan pendapatan yang ada untuk pengeluaran, sehingga akan memungkinkan dalam kekurangan dana untuk memberikan pelayanan publik kepada masyarakat atau mengalami kondisi financial distress.

Hasil penelitian ini berbeda dengan penelitian Lazyra (2016) dan Afifah (2017) yang menyatakan bahwa rasio efisiensi berpengaruh positif dan signifikan terhadap financial distress. Tingginya rasio efisiensi menggambarkan kinerja pemerintah daerah yang kurang baik dalam mengatur dana pengeluaran sehingga dana yang tersedia sedikit digunakan untuk belanja modal sehingga dapat menyebabkan financial distress. Tingkat rasio efisiensi tidak dapat menggambarkan financial distress secara langsung karena pada hasil penelitian rasio efisiensi berada dikisaran tingkat efisiens akan tetapi tingkat kondisi financial distress pada kabupaten/kota masih tinggi, maka rasio efisiensi tidak dapat menggambarkan alokasi belanja modal secara langsung.

\section{Pengaruh Rasio Solvabilitas Terhadap Financial Distress}

Hasil pengujian hipotesis ketiga menunjukkan nilai signifikansi 0,696 dan koefisien 0,123 . Nilai signifikansi dari rasio solvabilitas besar dari 0,05 sehingga menunjukkan bahwa rasio solvabilitas berpengaruh tidak signifikan terhadap financial distress. Nilai koefisien regresi dari rasio solvabilitas adalah positif 0,123 searah dengan hipotesis ketiga sehingga dapat dinyatakan bahwa hipotesis 3 (H3) diterima. Artinya secara parsial rasio solvabilitas berpengaruh positif dan tidak signifikan terhadap financial distress. Hal ini menggambarkan bahwa semakin tinggi rasio solvabilitas menandakan kinerja pemerintah daerah kurang bagus dan cenderung akan mengalami financial distress. Rasio solvabilitas ini menunjukkan kemampuan pemerintah daerah dalam melunasi hutangnya dengan aset yang ada. Namun hal tersebut tidak menjadi jaminan pemerintah daerah terbebas dari kondisi financial distress.

Hasil penelitian ini tidak sejalan dengan penelitian Indriaty (2016) yang menyatakan bahwa rasio hutang atau rasio solvabilitas berpengaruh signifikan terhadap financial distress. 
Pada penelitian ini rasio solvabilitas memiliki arah positif yang menandakan bahwa semakin tinggi rasio solvabilitas maka akan semakin tinggi tingkat financial distress pemerintah daerah. Hal tersebut dapat dilihat dari jumlah aset pemerintah daerah yang notabenenya untuk melunasi hutang yang tersedia namun dilakukan hal sebaliknya bahwa hutang digunakan untuk membiayai aset pemerintah daerah sehingga jumlah hutang semakin besar dan pemerintah daerah memiliki kesulitan dalam menetapkan anggaran.

\section{Pengaruh Rasio Pertumbuhan Terhadap Financial Distress}

Hasil pengujian hipotesis keempat memiliki nilai signifikansi 0,001 dan koefisien 0,108. Nilai signifikansi dari rasio pertumbuhan kecil dari 0,05 yang artinya rasio pertumbuhan berpengaruh signifikan terhadap financial distress. Nilai koefisien regresi dari rasio pertumbuhan adalah positif 0,108 tidak searah dengan arah hipotesis yang negatif. Sehingga dapat dinyatakan hipotesis keempat (H4) ditolak. Hasil penelitian menunjukkan bahwa secara simultan rasio pertumbuhan berpengaruh signifikan terhadap financial distress dan secara parsial rasio pertumbuhan berpengaruh positif dan signifikan terhadap financial distress.

Hasil penelitian ini tidak sejalan dengan penelitian yang dilakukan oleh Rusdi dan Fuad (2018) dengan arah hasil negatif yang menjelaskan bahwa semakin tinggi rasio pertumbuhan maka semakin rendah kecenderungan pemerintah daerah mengalami financial distress. Pada penelitian ini rasio pertumbuhan memiliki arah positif terhadap financial distress sehingga menunjukkan bahwa semakin tinggi rasio pertumbuhan semakin tinggi kecenderungan pemerintah daerah memiliki kondisi financial distress. Hal ini ditunjukkan oleh besarnya pendapatan asli daerah yang diperoleh oleh pemerintah daerah menandakan kinerja pemerintah daerah yang bagus. Namun untuk mendapatkan pendapatan asli daerah yang besar tersebut dibutuhkan biaya yang besar untuk memperolehnya, sehingga hasil yang diperoleh hanya sedikit dan dapat mengakibatkan financial distress (Rahayu dan Sopian, 2017).

\section{Pengaruh Derajat Desentralisasi Terhadap Financial Distress}

Hasil pengujian hipotesis kelima memiliki nilai signifikansi 0,004 dan nilai koefisien regresi $-0,609$. Nilai signifikansi dari derajat desentralisasi kecil dari 0,05 yang artinya derjat desentralisasi berpengaruh signifikan terhadap financial distress dan nilai koefisien regresi derajat desentralisasi negatif 0,609 searah dengan hipotesis kelima sehingga hipotesis kelima (H5) diterima. Maka dapat disimpulkan bahwa derajat desentralisasi berpengaruh negatif dan signifikan terhadap financial distress. Hasil penelitian ini sejalan dengan hasil penelitian Syurmita (2014), Sari dan Arza (2019) yang menyatakan bahwa derajat desentralisasi berpengaruh signifikan negatif terhadap financial distress. Hal tersebut menggambarkan bahwa semakin tinggi tingkat derajat desentralisasi pemerintah daerah maka semakin rendah kecenderungan pemerintah daerah mengalami kondisi financial distress.

Derajat desentralisasi pemerintah daerah menandakan kemampuan pemerintah daerah dalam mengelola pemerintah daerahnya sendiri sehingga pemerintah daerah yang dapat mengatur, mengelola dan menyusun pemerintah daerahnya sendiri tidak memiliki ketergantungan terhadap pemerintah pusat. Pemerintah daerah yang tidak memiliki ketergantungan penuh terhadap pemerintah pusat dapat mengandalkan pendapatan asli daerahnya untuk mengoptimalkan belanja modalnya yang digunakan untuk pelayanan publik yang sesuai dengan standar.

\section{Pengaruh Kompleksitas Pemerintah Daerah Terhadap Financial Distress}

Hasil pengujian hipotesis keenam memiliki nilai signifikansi 0,011 dan nilai koefisien regresi sebesar $-2,896$. Nilai signifikansi dari kompleksitas keuangan pemerintah daerah kecil 
dari 0,05 yang berarti kompleksitas keuangan pemerintah daerah berpengaruh signifikan terhadap financial distress. Nilai koefisien regresi kompleksitas keuangan pemerintah daerah sebesar negatif 2,896 tidak searah dengan hipotesis keenam sehingga dapat diartikan hipotesis keenam (H6) ditolak. Sehingga dapat disimpulkan secara simultan kompleksitas keuangan pemerintah daerah berpengaruh signifikan terhadap financial distress dan secara parsial kompleksitas keuangan pemerintah daerah berpengaruh negatif dan signifikan terhadap financial distress. Hal tersebut menggambarkan bahwa semakin banyak jumlah penduduk suatu daerah maka semakin rendah kecenderungan pemerintah daerah mengalami financial distress.

Hasil ini tidak sejalan dengan penelitian Husniati (2016), Sari dan Arza (2019) yang menyatakan bahwa jumlah penduduk berpengaruh positif terhadap financial distress. Banyaknya jumlah penduduk dapat menentukan kebutuhan pelayanan publik suatu pemerintah daerah. Akan tetapi dengan banyaknya jumlah penduduk tersebut juga memiliki kontribusi terhadap daerah berupa pajak dan retribusi daerah. Tidak hanya itu pertumbuhan dan perkembangan penduduk yang berkualitas akan meningkatkan efektivitas dan efisiensi kinerja pemerintah. Penduduk dapat berfungsi sebagai pengawas yang dapat mengevaluasi kinerja pemerintah daerah sehingga kecenderungan pemerintah mengalami kondisi financial distress semakin rendah.

\section{Pengaruh Luas Wilayah Terhadap Financial Distress}

Hasil pengujian hipotesis ketujuh memiliki nilai signifikansi 0,393 dan nilai koefisien regresi 0,533. Nilai signifikansi luas wilayah besar dari 0,05 sehingga luas wilayah berpengaruh tidak signifikan terhadap financial distress. Nilai koefisien regresi luas wilayah sebesar positif 0,533 searah dengan hipotesis ketujuh yang artinya hipotesis ketujuh $(\mathrm{H} 7)$ diterima. Maka dapat disimpulkan secara simultan luas wilayah berpengaruh tidak signifikan terhadap financial distress dan secara parsial luas wilayah berpengaruh positif dan tidak signifikan terhadap financial distress. Hal tersebut menggambarkan bahwa semakin besar luas wilayah maka semakin tinggi kecenderungan pemerintah daerah mengalami kondisi financial distress.

Hasil penelitian ini tidak sejalan dengan penelitian Sari dan Arza (2019), Cheisviyanny, dkk (2020), Wulandari dan Arza (2020) yang menyatakan bahwa luas wilayah berpengaruh signifikan terhadap financial distress. Besarnya luas wilayah dapat menggambarkan banyaknya kebutuhan sarana dan prasarana suatu wilayah. Namun hal tersebut belum sepenuhnya dapat menggambarkan kinerja pemerintah daerah dalam mengalokasikan belanja modal untuk pelayanan publik pada suatu pemerintah daerah.

\section{Pengaruh Opini Audit Terhadap Financial Distress}

Hasil pengujian hipotesis kedelapan memiliki nilai signifikansi 0,772 dan nilai koefisien regresi sebesar -0,809. Nilai signifikansi dari opini audit besar dari 0,05 sehingga opini audit berpengaruh tidak signifikan terhadap financial distress. Nilai koefisien regresi opini audit adalah sebesar negatif 0,809 searah dengan hipotesis kedelapan yang berarti hipotesis kedelapan (H8) diterima. Maka dapat disimpulkan secara simultan opini audit berpengaruh tidak signifikan terhadap financial distress dan secara parsial opini audit berpengaruh negatif dan tidak signifikan terhadap financial distress. Hal tersebut menandakan bahwa semakin wajar opini audit pemerintah daerah maka semakin rendah kecenderungan pemerintah daerah mengalami financial distress.

Hasil penelitian ini berbeda dengan penelitian Indriaty (2016), Wulandari dan Arza (2020) yang menyatakan bahwa opini audit berpengaruh positif dan tidak signifikan terhadap financial distress. Opini audit merupakan pernyataan terkait kewajaran informasi laporan keuangan pemerintah daerah yang diberikan oleh auditor BPK menyangkut tentang 
materialitas, posisi keuangan dan arus kas (Suryaningsih dan Sisdayani, 2016). Opini audit dapat menjadi tolak ukur untuk menetapkan anggaran pada tahun berikutnya yang dapat menggambarkan kinerja keuangan pemerintah daerah berdasarkan realisasi anggarannya. Persentase belanja modal yang tidak mencapai standar tidak dapat hanya dilihat dari alokasi belanja modal saja. Sehingga opini audit tidak dapat berpengaruh langsung kepada alokasi belanja modal dan kondisi financial distress pemerintah daerah. Dapat disimpulkan bahwa opini audit tidak memengaruhi kecenderungan pemerintah daerah mengalami kondisi financial distress dan rata-rata opini audit pada kabupaten/kota di provinsi Aceh mendapat opini audit Wajar Tanpa Pengecualian (WTP), akan tetapi tingkat persentase financial distress-nya masih tinggi yakni sebesar 70,4\%.

\section{SIMPULAN, KETERBATASAN DAN SARAN \\ Simpulan}

Berdasarkan pengolahan data dan analisis yang dilakukan maka dapat diperoleh kesimpulan sebagai berikut:

1. Hasil statistik deskriptif pada tabel 4.3 menunjukkan bahwa dari 23 kabupaten/kota di provinsi Aceh dengan pengamatan selama 5 tahun sehingga totalnya berjumlah 115 kabupaten/kota. Terdapat 81 kabupaten/kota yang mengalami financial distress dan terdapat 34 kabupaten/kota yang tidak mengalami financial distress. Total keseluruhan kondisi financial distress pada penelitian ini menunjukkan persentase $70,4 \%$ pada pemerintah daerah kabupaten/kota di provinsi Aceh. Artinya 70,4\% pemerintah daerah di kabupaten/kota provinsi Aceh mengalami kondisi kesulitan dana dalam memenuhi pelayanan publik ataupun kebutuhan masyarakat.

2. Nilai signifikansi dari rasio efektivitas sebesar 0,104 dan koefisien sebesar $-0,241$. Nilai signifikansi dari rasio efektivitas besar dari 0,05 sehingga mengambarkan bahwa rasio efektivitas berpengaruh tidak signifikan terhadap financial distress dan nilai koefisien dari rasio efektivitas yang negatif $-0,241$ menunjukkan arah dari rasio efektivitas sesuai dengan arah hipotesis yang pertama, namun tidak mampu membuktikan secara signifikan pengaruh rasio efektivitas terhadap financial distress sehingga hipotesis pertama (H1) ditolak.

3. Nilai signifikansi rasio efisiensi sebesar 0,770 dan koefisien sebesar $-0,017$. Nilai signifikansi dari rasio efisiensi besar dari 0,05 sehingga menggambarkan bahwa rasio efisiensi berpengaruh tidak signifikan terhadap financial distress. Nilai koefisiennya adalah sebesar negatif 0,017 hal ini berarti hipotesis kedua (H2) ditolak karena penelitian ini tidak dapat membuktikan bahwa rasio efisiensi berpengaruh positif dan signifikan terhadap financial distress.

4. Nilai signifikansi dari rasio solvabilitas sebesar 0,696 dan koefisien 0,123. Nilai signifikansi dari rasio solvabilitas besar dari 0,05 sehingga menunjukkan bahwa rasio solvabilitas berpengaruh tidak signifikan terhadap financial distress. Nilai koefisien regresi dari rasio solvabilitas adalah positif 0,123 tidak searah dengan hipotesis ketiga sehingga dapat dinyatakan bahwa hipotesis 3 (H3) ditolak, karena tidak dapat membuktikan bahwa rasio solvabilitas berpengaruh negatif dan signifikan terhadap financial distress.

5. Nilai signifikansi dari rasio pertumbuhan sebesar 0,001 dan koefisien 0,108. Nilai signifikansi dari rasio pertumbuhan kecil dari 0,05 yang artinya rasio pertumbuhan berpengaruh signifikan terhadap financial distress. Nilai koefisien regresi dari rasio pertumbuhan adalah positif 0,108 tidak searah dengan arah hipotesis yang negatif. Sehingga dapat dinyatakan hipotesis keempat (H4) ditolak, karena tidak dapat membuktikan bahwa rasio pertumbuhan berpengaruh negatif terhadap financial distress.

6. Nilai signifikansi dari derajat desentralisasi sebesar 0,004 dan nilai koefisien regresi $-0,609$. Nilai signifikansi dari derajat desentralisasi kecil dari 0,05 yang artinya derjat desentralisasi berpengaruh signifikan terhadap financial distress dan nilai koefisien regresi derajat 
desentralisasi negatif 0,609 searah dengan hipotesis kelima sehingga hipotesis kelima (H5) diterima.

7. Nilai signifikansi dari kompleksitas keuangan pemerintah daerah sebesar 0,011 dan nilai koefisien regresi sebesar -2,896. Nilai signifikansi dari kompleksitas keuangan pemerintah daerah kecil dari 0,05 yang berarti kompleksitas keuangan pemerintah daerah berpengaruh signifikan terhadap financial distress. Nilai koefisien regresi kompleksitas keuangan pemerintah daerah sebesar negatif 2,896 tidak searah dengan hipotesis keenam sehingga dapat diartikan hipotesis keenam (H6) ditolak. Karena tidak dapat membuktikan bahwa kompleksitas keuangan pemerintah daerah berpengaruh positif terhadap financial distress.

8. Nilai signifikansi dari luas wilayah sebesar 0,393 dan nilai koefisien regresi 0,533 . Nilai signifikansi luas wilayah besar dari 0,05 sehingga luas wilayah berpengaruh tidak signifikan terhadap financial distress. Nilai koefisien regresi luas wilayah sebesar positif 0,533 searah dengan hipotesis ketujuh, namun tidak dapat membuktikan bahwa luas wilayah berpengaruh signifikan terhadap financial distress sehingga hipotesis ketujuh $(\mathrm{H} 7)$ ditolak.

9. Nilai signifikansi opini audit adalah sebesar 0,772 dan nilai koefisien regresi sebesar $-0,809$. Nilai signifikansi dari opini audit besar dari 0,05 sehingga opini audit berpengaruh tidak signifikan terhadap financial distress. Nilai koefisien regresi opini audit adalah sebesar negatif 0,809 searah dengan hipotesis kedelapan, namun tidak dapat membuktikan bahwa opini audit berpengaruh signifikan terhadap financial distress sehingga hipotesis kedelapan (H8) ditolak.

\section{Keterbatasan}

Penelitian ini dirancang dengan sebaik-baiknya, namun penulis menyadari bahwa penelitian ini memiliki beberapa keterbatasan yaitu:

1. Penelitian ini belum mampu menjelaskan hasil signifikansi dari beberapa faktor keuangan dan beberapa karakteristik pemerintah daerah, hanya mampu menjelaskan tiga variabel yang signifikan terhadap financial distress.

2. Nilai Adjusted $\mathrm{R}$ Square adalah 0,357 atau sama dengan $35,7 \%$ yang artinya kontribusi variabel independen terhadap variabel dependen hanya 35,7\%. Sehingga masih banyak variabel lain diluar dari penelitian ini yang dapat memengaruhi financial distress pemerintah daerah.

\section{Saran Untuk Penelitian Selanjutnya}

Peneliti selanjutnya diharapkan mampu menjelaskan signifikansi dari variabel-variabel yang hasilnya tidak signifikan pada penelitian ini. Peneliti selanjutnya juga diharapkan untuk menambahkan variabel lain dari faktor keuangan dan karakteristik pemerintah daerah karena persentase variabel lain memengaruhi financial distress adalah 64,3\%. Peneliti selanjutnya juga diharapkan untuk menggunakan definisi financial distress sebagai ketidakmampuan pemerintah daerah dalam merealisasikan alokasi belanja modalnya sehingga pelayanan publik tidak terpenuhi dengan sesuai standai mutu yang telah ditetapkan.

\section{DAFTAR PUSTAKA}

Balcilar, Mehmet et al. 2017. Testing the Dependency Theory on Small Island Economies: The Case of Cyprus. Economic Modelling 61 (2017) 1-11.

Direktorat Jenderal Bina Keuangan Daerah Kementrian Dalam Negeri. (n.d.). Retrieved from Direktorat Jenderal Bina Keuangan Daerah Kementrian Dalam Negeri: www.kemendagri.go.id (diakses 12 Februari 2020).

Gorina, Evgenia et al. 2017. Local Fiscal Distress: Measurement and Prediction. Public Financial Publications. Inc. 
Halim, Abdul. 2012. Akuntansi Keuangan Daerah. Jakarta: Salemba Empat.

Husniati, Sri dkk. 2016. Faktor-faktor yang Mempengaruhi Financial Distress. Seminar Nasional Global Competitive Advantage hal 150.

Indriaty, Novica. 2016. Prediksi Financial Distress Pemerintah Daerah di Indonesia. Seminar Nasional \& Call of Paper 3.

Jones, S., and R.G. Walker. 2007. Explanators of Local Government Distress. ABACUS, Vol. 43, No. 3, 2007.

Kementerian Keuangan Republik Indonesia. (n.d.). Retrieved from Kementerian Keuangan Republik Indonesia: https://www.kemenkeu.go.id/publikasi/artikeldan-opini/pemenuhan-anggaran-infrastruktur-di-daerah-dan-tantangannya/. (diakses 12 Februari 2020).

Lazyra, KS. 2016. Analisis Rasio Keuangan Daerah dalam Menilai Kinerja Keuangan Pemerintah Kota Medan. Skripsi.

Marco Bisogno et al. 2018. Budgetary Solvency of Italian Local Governments: An Assessment. International Journal of Public Sector Management.

Michael C. Jensen \& William H. Meckling. 1976. Theory of The Firm: Managerial Behavior, Agency Costs and Ownership Structure. Jurnal of Financial Economics 3 (1976) 305-360.

Ombudsman Republik Indonesia. (n.d.). Retrieved from Ombudsman Republik Indonesia: humas@ombudsman.go.id (diakses 15 Februari 2020).

Paul, Abhijeet. 2016. Dependency Theory. The Encyclopedia of Empire, First Edition.

Peraturan Menteri Keuangan Nomor 139/PMK.07/2019 tentang Pengelolaan Dana Bagi Hasil, Dana Alokasi Umum dan Dana Alokasi Khusus.

Peraturan Presiden RI No. 2 tahun 2015.

Pratiwi, Mutiara Galuh. 2014. Prediksi Status Financial Distress Pemerintah Daerah Kabupaten/Kota di Indonesia tahun 2014. Skripsi.

Sandra Cohen Antonella Costanzo Francesca Manes-Rossi. 2017. Auditors and early signals of financial distress in Local Governments. Managerial Auditing Journal, Vol. 32 Iss 3 pp.

Sari, Mutiara \& Arza, F.I. 2019. Pengaruh Karakteristik Pemerintah Daerah Terhadap Kondisi Financial Distress Pemerintah Daerah Kabupaten dan Kota SeIndonesia Periode 2015-2017. Wahana Riset Akuntansi Vol. 7, No 1, April 2019, Hal 1425-1436.

Setiawan, Mia Angelina. 2018. The Economy Crisis and Financial Performance. Advances in Economics, Business and Management Research, volume 57, 1st International Conference On Economics Education, Economics, Business and Management, Accounting and Entrepreneurship (PICEEBA 2018).

Suryaningsih, Ni Made \& Sisdyani, Eka Ardhani. 2016. Karakteristik Pemerintah Daerah dan Opini Audit pada Kinerja Keuangan Pemerintah Daerah. E-Jurnal Akuntansi Universitas Udayana Vol.15.2.Mei (2016):1453-1481.

Sutaryo, dkk. 2010. Nilai Relevan Informasi Laporam Keuangan Terkait Financial Distress Pemerintah Daerah. Simposium Nasional Akuntansi XIII. Purwokerto.

Syurmita. 2014. Pengaruh Karakteristik Daerah terhadap Prediksi Financial Distress. SNA. XVII. Mataram.

Undang-Undang No. 32 Tahun 2004 Tentang Pemerintah Daerah. 
Waninda \& Arza, Fefri Indra. 2019. Relevansi Informasi Laporan Keuangan Accrual Basis: Kemampuan Rasio Keuangan dalam Memprediksi Status Financial Distress Pemerintah Daerah Kabupaten dan Kota se-Indonesia Periode 20152017. Jurnal Eksplorasi Akuntansi Vol. 1, No.2, Seri C, Mei 2019, Hal 795-813. Windiyanti, Rury \& Isfaatun, Ellya. 2017. Pengaruh Kemandirian Keuangan, Rasio Solvabilitas, Kompleksitas dan Umur Pemerintahan terhadap Financial Distress Pemerintah Daerah Kabupaten/Kota di Indonesia. ISSN-1411-3880.

Wulandari, dkk. 2018. Faktor-Faktor yang Mempengaruhi Financial Distress Pemerintah Daerah. JRAMB, Prodi Akuntansi, Fakultas Ekonomi, UMB Yogyakarta, Volume 4 No. 2., November 2018.

Wulandari, Yoli \& Arza, F.I. 2020. Pengaruh Faktor Keuangan dan Karakterisik Pemerintah Daerah Terhadap Financial Distress (Studi Empiris pada Kabupaten/ Kota di Sumatera Barat Tahun 2015 -2018). Jurnal Eksplorasi Akuntansi, 2(3), Seri C, 3179-3196.

Yanti, Rida Damai. 2018. Kemampuan Rasio Keuangan dalam Memprediksi Status Financial Distress Pemerintah Daerah Kabupaten/Kota di Provinsi Sumatera Barat Periode 2012-2016. Jurnal Eksplorasi Akuntansi. 


\section{LAMPIRAN}

\section{Analisis Deskriptif}

\begin{tabular}{|l|r|r|r|r|r|}
\hline \multicolumn{7}{|c|}{ Descriptive Statistics } \\
\hline & $\mathrm{N}$ & Minimum & Maximum & Mean & Std. Deviation \\
\hline Rasio Efektivitas (X1) & 115 & 76,98 & 118,30 & 96,5143 & 4,37868 \\
\hline Rasio Efisiensi (X2) & 115 & 56,30 & 126,12 & 85,7528 & 10,20603 \\
\hline Rasio Solvabilitas (X3) & 115 &, 00 & 16,83 & 1,9322 & 2,21255 \\
\hline Rasio Pertumbuhan (X4) & 115 & $-28,01$ & 65,20 & 11,5237 & 18,26557 \\
\hline $\begin{array}{l}\text { Derajat Desentralisasi } \\
\text { (X5) }\end{array}$ & 115 & 3,58 & 23,20 & 9,4354 & 3,72781 \\
\hline Kompleksitas Pemda (X6) & 115 & 10,41 & 13,34 & 12,1237 &, 66676 \\
\hline Luas Wilayah (X7) & 115 & 4,10 & 8,75 & 7,3909 & 1,21860 \\
\hline Opini Audit (X8) & 115 & 0 & 1 &, 96 &, 205 \\
\hline Financial Distress (Y) & 115 & 9,63 & 46,50 & 26,2010 & 7,07855 \\
\hline Valid N (listwise) & 115 & & & & \\
\hline
\end{tabular}

\section{Classification Table}

\begin{tabular}{|c|c|c|c|c|c|}
\hline \multicolumn{6}{|c|}{ Classification Table ${ }^{a, b}$} \\
\hline & \multirow{3}{*}{\multicolumn{2}{|c|}{ Observed }} & \multicolumn{3}{|c|}{ Predicted } \\
\hline & & & \multicolumn{2}{|c|}{ Financial Distress $(\mathrm{Y})$} & \multirow[b]{2}{*}{$\begin{array}{l}\text { Percentage } \\
\text { Correct }\end{array}$} \\
\hline & & & $\begin{array}{l}\text { Financial } \\
\text { Distress }\end{array}$ & $\begin{array}{c}\text { Non } \\
\text { Financial } \\
\text { Distress }\end{array}$ & \\
\hline \multirow[t]{3}{*}{ Step 0} & \multirow{2}{*}{$\begin{array}{l}\text { Financial Distress } \\
\text { (Y) }\end{array}$} & Financial Distress & 81 & 0 & 100,0 \\
\hline & & \begin{tabular}{|l|} 
Non Financial \\
Distress
\end{tabular} & 34 & 0 & ,0 \\
\hline & \multicolumn{2}{|l|}{ Overall Percentage } & & & 70,4 \\
\hline \multicolumn{6}{|c|}{ a. Constant is included in the model. } \\
\hline \multicolumn{6}{|c|}{ b. The cut value is, 500} \\
\hline
\end{tabular}

\section{Analisis Regresi Linear Berganda}

\begin{tabular}{|c|c|c|c|c|c|c|c|}
\hline \multicolumn{8}{|c|}{ Coefficients $^{a}$} \\
\hline \multirow[b]{2}{*}{ Model } & \multicolumn{2}{|c|}{$\begin{array}{c}\text { Unstandardized } \\
\text { Coefficients }\end{array}$} & \multirow{2}{*}{$\begin{array}{c}\begin{array}{c}\text { Standardiz } \\
\text { ed } \\
\text { Coefficient } \\
\text { s }\end{array} \\
\text { Beta }\end{array}$} & \multirow[b]{2}{*}{ T } & \multirow[b]{2}{*}{ Sig. } & \multicolumn{2}{|c|}{$\begin{array}{l}\text { Collinearity } \\
\text { Statistics }\end{array}$} \\
\hline & $\mathrm{B}$ & Std. Error & & & & $\begin{array}{c}\text { Toleran } \\
\text { ce }\end{array}$ & VIF \\
\hline (Constant) & 87,204 & 20,658 & & 4,221 &, 000 & & \\
\hline Rasio Efektivitas &,- 241 & , 147 &,- 149 & $-1,639$ & ,104 & ,679 & 1,472 \\
\hline Rasio Efisiensi &,- 017 &, 059 &,- 025 &,- 294 & ,770 & ,768 & 1,301 \\
\hline $\begin{array}{l}\text { Rasio } \\
\text { Solvabilitas }\end{array}$ & ,123 & ,314 & ,038 & ,392 & ,696 & ,584 & 1,711 \\
\hline $\begin{array}{l}\text { Rasio } \\
\text { Pertumbuhan }\end{array}$ & , 108 & ,030 & ,279 & 3,567 & ,001 & ,923 & 1,084 \\
\hline $\begin{array}{l}\text { Derajat } \\
\text { Desentralisasi }\end{array}$ &,- 609 & ,207 &,- 321 & $-2,942$ & ,004 & ,474 & 2,108 \\
\hline $\begin{array}{l}\text { Kompleksitas } \\
\text { Pemda }\end{array}$ & $-2,896$ & 1,124 &,- 273 & $-2,577$ & ,011 & ,503 & 1,987 \\
\hline Luas Wilayah &, 533 &, 622 &, 092 &, 857 & ,393 & ,491 & 2,036 \\
\hline Opini Audit &,- 809 & 2,786 &,- 023 &,- 290 & ,772 & ,868 & 1,153 \\
\hline
\end{tabular}


4. Uji Kolmogorov-Smirnov Test

\begin{tabular}{|l|l|r|}
\hline \multicolumn{2}{|c|}{ One-Sample Kolmogorov-Smirnov Test } \\
\hline $\mathrm{N}$ & Unstandardized Residual \\
\hline \multirow{2}{|l|}{ Normal Parameters ${ }^{\text {a,b }}$} & 115 \\
\hline \multirow{2}{*}{ Most Extreme Differences } & Mean &, 0000000 \\
\cline { 2 - 3 } & Std. Deviation & 5,47285556 \\
\cline { 2 - 3 } & Absolute &, 064 \\
\cline { 2 - 3 } & Positive &, 062 \\
\hline \multicolumn{2}{|l|}{ Test Statistic } &,- 064 \\
\hline Asymp. Sig. (2-tailed) &, 064 \\
\hline a. Test distribution is Normal. &, $200^{\text {c,d }}$ \\
\hline b. Calculated from data. \\
\hline \multicolumn{2}{|l|}{ c. Lilliefors Significance Correction. } \\
\hline d. This is a lower bound of the true significance. \\
\hline
\end{tabular}

\section{Uji Heteroskedastisitas}

Scatterplot

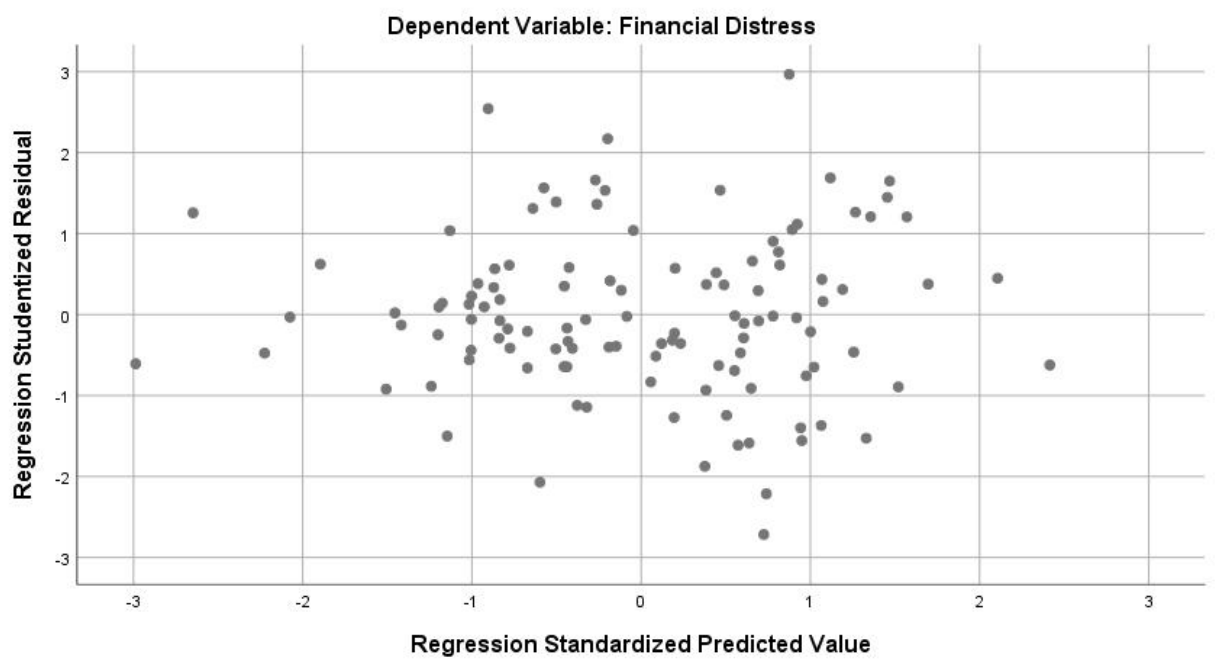

6. Adjusted R Square

\begin{tabular}{|c|c|c|c|c|c|c|c|c|c|c|}
\hline \multicolumn{11}{|c|}{ Model Summaryb } \\
\hline \multirow[b]{2}{*}{$\begin{array}{l}\text { Mo } \\
\text { del }\end{array}$} & \multirow[b]{2}{*}{$\mathrm{R}$} & \multirow[b]{2}{*}{$\begin{array}{c}\mathrm{R} \\
\text { Square }\end{array}$} & \multirow[b]{2}{*}{$\begin{array}{l}\text { Adjust } \\
\text { ed R } \\
\text { Square }\end{array}$} & \multirow{2}{*}{$\begin{array}{c}\text { Std. } \\
\text { Error of } \\
\text { the } \\
\text { Estimate }\end{array}$} & \multicolumn{5}{|c|}{ Change Statistics } & \multirow[b]{2}{*}{$\begin{array}{l}\text { Durbin- } \\
\text { Watson }\end{array}$} \\
\hline & & & & & $\begin{array}{c}\mathrm{R} \\
\text { Square } \\
\text { Change }\end{array}$ & $\begin{array}{c}\mathrm{F} \\
\text { Change }\end{array}$ & df1 & $\mathrm{df2}$ & $\begin{array}{l}\text { Sig. F } \\
\text { Chang } \\
e\end{array}$ & \\
\hline 1 & $634^{a}$ & ,402 & ,357 & 5,67562 & ,402 & 8,915 & 8 & 106 &, 000 & 1,453 \\
\hline
\end{tabular}

a. Predictors: (Constant), Opini Audit, Luas Wilayah, Rasio Pertumbuhan, Rasio Efektivitas, Kompleksitas Pemda, Rasio Efisiensi, Rasio Solvabilitas, Derajat Desentralisasi

b. Dependent Variable: Financial Distress 


\section{Uji F}

\begin{tabular}{|c|c|c|c|c|c|c|}
\hline \multicolumn{7}{|c|}{ ANOVA $^{a}$} \\
\hline \multicolumn{2}{|l|}{ Model } & Sum of Squares & Df & Mean Square & $\mathrm{F}$ & Sig. \\
\hline \multirow[t]{3}{*}{1} & Regression & 2297,522 & 8 & 287,190 & 8,915 &, $000^{\mathrm{b}}$ \\
\hline & Residual & 3414,545 & 106 & 32,213 & & \\
\hline & Total & 5712,067 & 114 & & & \\
\hline \multicolumn{7}{|c|}{ a. Dependent Variable: Financial Distress } \\
\hline \multicolumn{7}{|c|}{$\begin{array}{l}\text { b. Predictors: (Constant), Opini Audit, Luas Wilayah, Rasio Pertumbuhan, Rasio Efektivitas, } \\
\text { Kompleksitas Pemda, Rasio Efisiensi, Rasio Solvabilitas, Derajat Desentralisasi }\end{array}$} \\
\hline
\end{tabular}

